\section{New Trends and Issues Proceedings on Humanities and Social Sciences}

Issue 1 (2017) 506-513

ISSN 2421-8030

www.prosoc.eu

Selected paper of 8th World Conference on Educational Sciences (WCES-2016), 4-8, February 2016, University of Alcala, Madrid, Spain

\title{
The effect of concept map based education on the problem solving skills of students
}

Mevlude Karadaga *, Department of Nursing, Faculty of Health Sciences, Gazi University Ankara, 06000, Turkey. Sevil Guler Demirb , Department of Nursing, Faculty of Health Sciences, Gazi University Ankara, 06000, Turkey. Hulya Bulut ${ }^{c}$, Department of Nursing, Faculty of Health Sciences, Gazi University Ankara, 06000, Turkey. Sevilay Erden ${ }^{d}$, Department of Nursing, Faculty of Health Sciences, Cukurova University, Adana,01000, Turkey.

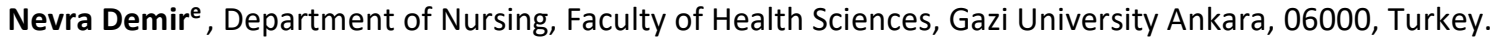
Zuhal Erdogan ${ }^{f}$, Department of Nursing, Faculty of Health Sciences, Gazi University Ankara, 06000, Turkey. Ali $\mathbf{A y}^{\mathrm{g}}$, Department of Nursing, Faculty of Health Sciences, Gazi University Ankara, 06000, Turkey.

\section{Suggested Citation:}

Karadag, M., Demir, S. G., Bulut, H., Erden, S., Demir, N., Erdogan, Z. \& Ay, A. (2017), The effect of concept map based education on the problem solving skills of students. New Trends and Issues Proceedings on Humanities and Social Sciences. [Online]. 01, pp 506-513. Available from: www.prosoc.eu

Selection and peer review under responsibility of Jesus Garcia Laborda, University of Alcala, Spain ${ }^{\circ} 2017$ SciencePark Research, Organization \& Counseling. All rights reserved.

\begin{abstract}
This study was carried out semi-experimentally to evaluate the effect of concept map based-teaching on nursing students' problem solving skills. The students who took the course in fall term were determined as control and those who took it in spring term were determined as experimental group. Both groups were simultaneously administered Student Information Form and Problem Solving Scale (PSS) at the beginning of the fall term, and PSS at the end of the fall and spring terms.It was also found that PSS increased significantly at the beginning of the course period in the experimental group, and that although there was not a statistically significant difference between the groups at the end of the term regarding PSS mean scores, There was a positive and significant relationship between the increase in academic achievement and problem solving skills of the experimental group students. It is recommended that concept map based education should be used as a method providing effective learning in nursing education to enhance problem solving skills and academic success positively.
\end{abstract}

Keywords: Concept map, problem solving skill, nursing.

* ADDRESS FOR CORRESPONDENCE: Mevlude Karadag, Department of Nursing, Faculty of Health Sciences, Gazi University Ankara, 06000, Turkey.

E-mail address: mevludekaradag@gmail.com / +90 31221626 00. 2905

One of the methods that enhances effective learning skills is concept mapping (Austin Community College District, n.d.). 
Karadag, M., Demir, S. G., Bulut, H., Erden, S., Demir, N., Erdogan, Z. \& Ay, A. (2017), The effect of concept map based education on the problem solving skills of students. New Trends and Issues Proceedings on Humanities and Social Sciences. [Online]. 01, pp 506-513. Available from: $\underline{w w w . p r o s o c . e u}$

\section{Introduction}

Since nursing is a profession mainly involving treatment and care, it requires the utilization of critical thinking and problem solving skills. For this reason, today's nursing education aims to grow up individuals who can reason, think critically, produce, know the ways to access information, and have learnt to learn rather than rote learning (Mahmoud, 2012). However, nursing students meet a lot of concepts that they have to understand during their education. Students can solve problems more easily by establishing a relationship between information clusters, and thus effective learning takes place provided that concepts are presented in a comprehensive way (All \& Havens, 1997).

Concept mapping is a teaching and learning technique that helps students to understand definitions by creating a visual map between concepts. This map allows students to associate their previous knowledge with each other, establish a link between this knowledge and newly acquired knowledge, and organize their plans reasonably (Austin Community College District, n.d.). It was determined in studies carried out with nursing students that the use of concept mapping enhanced the critical thinking scores of students during the term when they had not attended clinical practice yet, and that this method, for this reason, encouraged students to think critically (Atay \& Karabacak, 2010; Chen, Liang, Lee \& Liao, 2011; Lee et al., 2013; Pickens, 2007). Research investigating the effect of concept map use on the critical thinking and problem solving skills of nursing students in our country is limited. However, utilization of critical thinking skills while making clinical decisions in patient care plans will enhance the problem solving skills of students.

\section{Materials and Method}

\subsection{Purpose}

This study was conducted as a quasi-experimental research to evaluate the effect of studying with concept map on the problem solving skills of students.

\subsection{The sampling of the study}

The sampling of the study was made up of students (119 students) registered at the nursing department of a Faculty of Health Sciences in Ankara city and receiving surgical nursing course in 2013-2014 academic year, and voluntarily agreeing to participate in the study. The students who received the surgical nursing course in fall term made up the control group (59 students), whereas those who received it in spring term constituted the experimental group (60 students).

\subsection{Study setting and its features}

The nursing students received the Surgical Nursing course in the $2^{\text {nd }}$ year for 15 weeks in a 14 hours / a week fashion ( 6 hours / week theoretical -8 hours / week clinical practice). The theoretical part of the course was generally studied using such techniques as lecturing, question - answer, discussion, case analysis, and group work. In clinical practice, on the other hand, students prepared care plans for the patients they followed, and they discussed these care plans with clinical educators.

\subsection{Data collection tools}

Student information form developed by the researchers, involved 24 items questioning students' sociodemographic features, education and social activities, critical thinking trends, and problem solving skills. Problem Solving Inventory (PSI) was developed by Heppner and Peterson (1982). It was designed to assess what individuals think about their own problem solving attitudes and approaches. 
Karadag, M., Demir, S. G., Bulut, H., Erden, S., Demir, N., Erdogan, Z. \& Ay, A. (2017), The effect of concept map based education on the problem solving skills of students. New Trends and Issues Proceedings on Humanities and Social Sciences. [Online]. 01, pp 506-513. Available from: $\underline{w w w . p r o s o c . e u}$

It has three sub-scales such as problem solving confidence (PSC), approach avoidance style (AAS), and personal control (PC) (Taylan, 1990).

\subsection{Implementation of the study}

The students in the control group were administered the current program of the surgical nursing course. The students in the experimental group received education on concept mapping in the first lesson. The first concept map was made with the teacher in the classroom while summarizing the lesson. In addition to the current program, the students in the experimental group prepared a concept map subsequent to studying each main subject. The students in both groups were administered Student Information Form and PSI at the beginning of the fall term, and PSI at the end of the fall and spring terms.

\subsection{Data analysis}

Descriptive statistics, Friedman's Two-Way ANOVA, Mann Whitney-U and Kruskal Wallis-H tests were used in the analysis of the data.

\subsection{Ethical and legal aspects of the study}

Official permission for the study was taken from the Ethical Committee of the University (No: 68, Date: 09 October, 2013). Written permission was obtained from the Faculty of Health Sciences, where the study was conducted. Additionally, informed consent of the students participating in the study was obtained.

\section{Findings}

There was not a significant difference between the experimental and control groups in terms of their informative features $(p>0,05)$. In addition, there was no significant difference between the average studying hours of the groups (experimental: $3,26 \pm 1,16$; control:2,78 $\pm 1,12$ ) and their academic mean scores prior to and while receiving surgical nursing course $(p>0,05)$.

There was no significant difference between the PSI sub-scale scores and total scores of the groups based on assessments within the group $(p>0,05)($ Table 1$)$. At the end of the fall term, the total score for problem solving confidence and the scores for approach avoidance style sub-scale was significantly lower in the experimental group $(p<0,05)$. This finding indicated that the problem solving skills of the students in the experimental group was higher than those of the control group. However, it was determined at the end of the spring term that there was no significant difference between the subscale scores of the students' problem solving skills and their total scores ( $p>0.05)$ (Table 1 ). 
Karadag, M., Demir, S. G., Bulut, H., Erden, S., Demir, N., Erdogan, Z. \& Ay, A. (2017), The effect of concept map based education on the problem solving skills of students. New Trends and Issues Proceedings on Humanities and Social Sciences. [Online]. 01, pp 506-513. Available from: $\underline{w w w . p r o s o c . e u}$

Table 1. The Distribution of the Difference between Experimental and Control Group Students' Problem

Solving Inventory Sub-Scale and Total Mean Scores

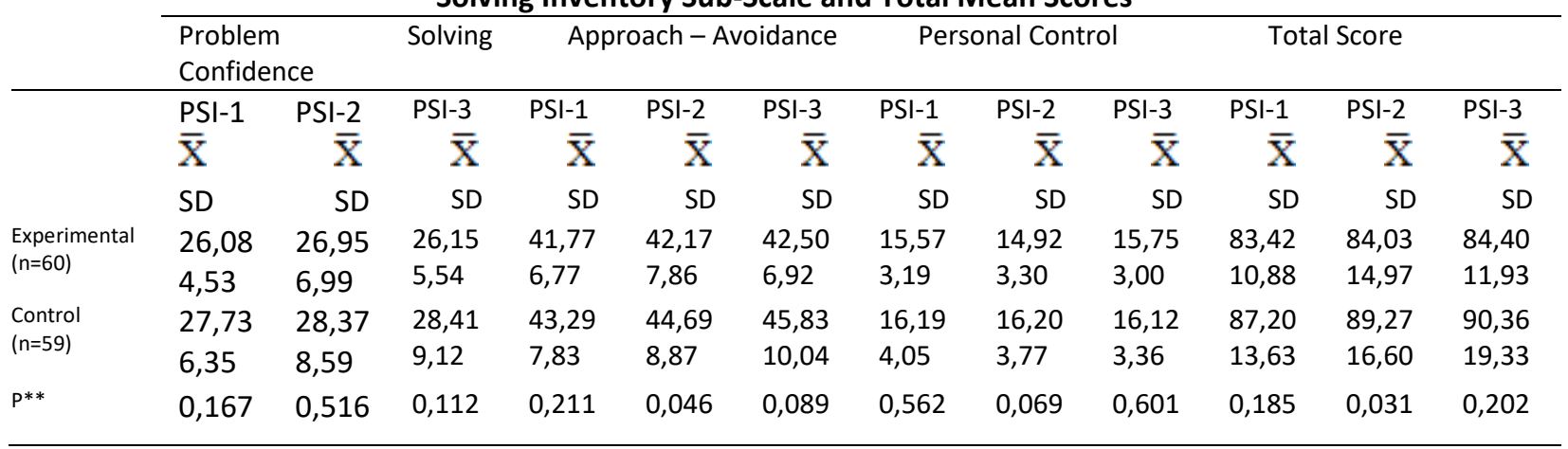

**Mann-Whitney $U$ test was employed.

PSI-1: PSI mean score implemented at the beginning of the fall term / PSI-2: PSI mean score implemented at the end of the fall term / PSI-3: PSI mean score implemented at the end of the spring term

It was found that there was a statistically significant difference between students' genders in terms of the experimental group students' problem solving confidence sub-scale score of the PSI administered at the beginning and end of the fall term $(p<0,05)$. The problem solving skills of the male students at the beginning and end of the fall tern in the experimental group were determined to be higher than those of the female students. There was no statistically significant difference between genders in terms of sub-scale and total scores of the students in the control group $(p>0,05)$. There was not a statistically significant difference between the graduated high schools of the students in the experimental group in terms of sub-scale and total scores $(p>0,05)$. On the other hand, there was a statistically significant difference between the graduated high schools of the students in the control group in terms of personal control sub-scale score of the PSI at the beginning of the fall term and at the end of the spring term $(p<0,05)$. The problem solving skills of the high school graduates in the control group at the end of the fall term was determined to be higher. However, it was found that the problem solving skills of Anatolian / Science High School graduates in the control group at the end of the spring term were higher. 
Karadag, M., Demir, S. G., Bulut, H., Erden, S., Demir, N., Erdogan, Z. \& Ay, A. (2017), The effect of concept map based education on the problem solving skills of students. New Trends and Issues Proceedings on Humanities and Social Sciences. [Online]. 01, pp 506-513. Available from: www.prosoc.eu

Table 2. The correlation distribution relating to the relationship between the experimental and control group students' academic mean scores of the term before taking the course and the term while taking the

course

\begin{tabular}{|c|c|c|c|c|c|c|c|c|c|c|c|c|c|}
\hline & \multicolumn{3}{|c|}{$\begin{array}{ll}\text { Problem } & \text { Solving } \\
\text { Confidence } & \end{array}$} & \multicolumn{3}{|c|}{$\begin{array}{l}\text { Approach } \\
\text { Avoidance }\end{array}$} & \multicolumn{3}{|c|}{ Personal Control } & \multicolumn{3}{|c|}{ Total Score } \\
\hline & & PSI-1 & PSI-2 & PSI-3 & $\begin{array}{l}\text { PSI- } \\
1\end{array}$ & PSI-2 & PSI-3 & PSI-1 & PSI-2 & PSI-3 & PSI-1 & PSI-2 & PSI-3 \\
\hline & & $\begin{array}{l}\mathrm{r} \\
\mathrm{P}\end{array}$ & $\begin{array}{l}\mathrm{r} \\
\mathrm{p}\end{array}$ & $\begin{array}{l}R \\
p\end{array}$ & $\begin{array}{l}\mathrm{r} \\
\mathrm{p}\end{array}$ & $\begin{array}{l}\mathrm{r} \\
\mathrm{p}\end{array}$ & $\begin{array}{l}\mathrm{r} \\
\mathrm{p}\end{array}$ & $\begin{array}{l}\mathrm{r} \\
\mathrm{p}\end{array}$ & $\begin{array}{l}\mathrm{r} \\
\mathrm{p}\end{array}$ & $\begin{array}{l}\mathrm{r} \\
\mathrm{p}\end{array}$ & $\begin{array}{l}\mathrm{r} \\
\mathrm{p}\end{array}$ & $\begin{array}{l}R \\
P\end{array}$ & $\begin{array}{l}\mathrm{r} \\
\mathrm{p}\end{array}$ \\
\hline \multirow{2}{*}{$\begin{array}{l}\text { Academi } \\
c \text { mean } \\
\text { score for } \\
\text { the term } \\
\text { before } \\
\text { taking } \\
\text { the } \\
\text { course* } \\
* *\end{array}$} & $\begin{array}{l}\text { Experimen } \\
\text { tal } \\
(n=60)\end{array}$ & $\begin{array}{l}-, 090 \\
0,49 \\
3\end{array}$ & $\begin{array}{l}64^{, 0} \\
026^{0}\end{array}$ & $\begin{array}{r}- \\
, 204 \\
0 \\
, 117\end{array}$ & $\begin{array}{r}- \\
, 204 \\
0 \\
118\end{array}$ & $\begin{array}{l}9^{-} \\
9^{0,3}\end{array}$ & $\begin{array}{r}- \\
, 371 \\
0 \\
003\end{array}$ & $\begin{array}{l}- \\
.082 \\
0,5\end{array}$ & $\begin{array}{c}- \\
040 \\
0,7\end{array}$ & $\begin{array}{c}- \\
0,093 \\
01\end{array}$ & $\begin{array}{c}- \\
.188 \\
49^{0,1}\end{array}$ & $\begin{array}{r}- \\
, 037 \\
0 \\
776\end{array}$ & $\begin{array}{l}-\overline{-} \\
0,334 \\
0,0\end{array}$ \\
\hline & $\begin{array}{l}\text { Control } \\
(n=59)\end{array}$ & $\begin{array}{r}117 \\
0 \\
, 377\end{array}$ & $\begin{array}{r}154 \\
0 \\
244\end{array}$ & $\begin{array}{r}, 010 \\
0 \\
, 939\end{array}$ & $\begin{array}{r}- \\
, 017 \\
0 \\
900\end{array}$ & $\begin{array}{c}- \\
.038 \\
0,7 \\
74\end{array}$ & $\begin{array}{r}- \\
, 028 \\
0 \\
832\end{array}$ & $1_{73^{, 02}} 0,8$ & $1_{48^{19}}{ }^{, 19}$ & $6^{., 15}$ & $1_{00^{, 05}}^{0,7}$ & $\begin{array}{c}03^{, 1} \\
0, \\
439\end{array}$ & $7_{97^{0,8}}^{01}$ \\
\hline \multirow{2}{*}{\begin{tabular}{l} 
Acad \\
emic \\
mean \\
\multicolumn{1}{c}{ score } \\
for the \\
term \\
when \\
the \\
course \\
was \\
taken \\
$* * *$
\end{tabular}} & $\begin{array}{l}\text { Experim } \\
\text { ental } \\
\quad(n=60)\end{array}$ & $\begin{array}{r}- \\
, 061 \\
0 \\
644\end{array}$ & $\begin{array}{r}- \\
005 \\
0 \\
970\end{array}$ & $\begin{array}{c}- \\
, 184 \\
0,1 \\
60^{0,1}\end{array}$ & $\begin{array}{r}- \\
, 234 \\
0 \\
072\end{array}$ & $\begin{array}{c}-\bar{c} \\
0,4 \\
41\end{array}$ & $\begin{array}{r}- \\
, 297 \\
, 021\end{array}$ & $4^{4} 2^{0,5}$ & $2^{2} 6^{0,9}$ & $\begin{array}{c}- \\
.055 \\
0,6 \\
79^{0}\end{array}$ & $\begin{array}{c}- \\
149 \\
56\end{array}$ & $\begin{array}{r}- \\
055 \\
0 \\
676\end{array}$ & $\begin{array}{c}- \\
, 271 \\
36\end{array}$ \\
\hline & $\begin{array}{l}\text { Control } \\
(n=59)\end{array}$ & $\begin{array}{c}40^{, 0} \\
765^{\circ}\end{array}$ & $\begin{array}{r}- \\
, 119 \\
0 \\
368\end{array}$ & $4_{87^{, 05}}^{0,6}$ & $\begin{array}{r}- \\
, 001 \\
0 \\
992\end{array}$ & $\begin{array}{l}-162 \\
0,2 \\
01^{0,2}\end{array}$ & $\begin{array}{c}10^{, 0} \\
939^{\circ}\end{array}$ & ${ }_{47^{-}}^{-}$ & $00^{, 00}$ & $8_{31}{ }^{0,8}$ & $5_{70^{0,9}}^{00}$ & $\begin{array}{r}- \\
148 \\
0 \\
263\end{array}$ & $6^{69^{0,7}}$ \\
\hline
\end{tabular}

*** Spearman's correlation coefficient was utilized.

There was not a statistically significant difference between whether there was an environmental factor affecting studying in terms of sub-scale and total scores of students in the experimental group $(p>0,05)$. It was determined that problem solving skills of the students who did not have an environmental factor affecting studying were higher in control group students at the beginning of the fall term in terms of personal control sub-scale score. It was also found that there was a statistically significant difference between problem solving total score and approach avoidance style sub-scale score and the academic mean score of the term before surgical nursing course in the experimental group students at the end of the spring term $(p<0,05)$ (Table 2$)$. Although this relationship was statistically significant, it was negative and weak. As the problem solving skills of the students in the experimental group decreased, the academic mean score in the term before the surgical course decreased as well. There was not a statistically significant difference between sub-scale and total scores and the academic mean score of the term before the surgical course in control group students $(p>0,05)$ (Table 2).

PSI-1: PSI mean score implemented at the beginning of the fall term / PSI-2: PSI mean score implemented at the end of the fall term / PSI-3: PSI mean score implemented at the end of the spring term

It was found that there was a statistically significant difference between experimental group students' problem solving total score and approach avoidance sub-scale score and the academic mean score of the term before the surgical course at the end of the spring term $(p<0,05)$. Though this relationship was statistically significant, it was negative and weak. As the academic mean score of the term when the surgical course was taken at the end of the spring term in experimental group students 
Karadag, M., Demir, S. G., Bulut, H., Erden, S., Demir, N., Erdogan, Z. \& Ay, A. (2017), The effect of concept map based education on the problem solving skills of students. New Trends and Issues Proceedings on Humanities and Social Sciences. [Online]. 01, pp 506-513. Available from: $\underline{w w w . p r o s o c . e u}$

increased, problem solving total score and approach avoidance sub-scale score decreased. This finding can suggest that the increase in academic mean score in the group studying with concept mapping increased problem solving skill. On the other hand, there was not a statistically significant difference between the control group students' sub-scale and total scores and the academic mean score of the term when the surgical course was taken $(p>0,05)$.

\section{Discussion}

Problem solving is an intellectual skill that can be developed through education and experience (Kelleci, GOlbası, Dogan \& Tugut, 2011; Tok \& Sevinc, 2010). Nursing students are expected to improve these features of theirs during their education (Kelleci et al., 2011). This study was carried out to assess the effect of concept map on the development of nursing students' problem solving skills. It was determined in the study that the problem solving skill mean scores for experimental and control group students ranged between 83.42 and 90.36 . When considered that the total score range that can be obtained from the inventory was $32-192$, and that as the scores obtained from the inventory decreased, the individual perceived himself/herself as a better problem solver, the problem solving skills of the students were determined to be above intermediate level.

When the related literature is reviewed, it can be seen that studies investigating the problem solving skills of the nursing students in Turkey have yielded various results. The PS mean scores of the nursing students was found $82.37 \pm 19.23$ in Durmaz et al. (2007). It was found $84.74 \pm 19.00$ in Altun (2003) and $80.25 \pm 17.00$ in Yurttas and Yetkin (2003). The findings of this study were found to be in line with the findings of the related studies.

It was noteworthy that the problem solving skills of both experimental and control group students in our study were determined to develop especially in the first assessment; however that there was a decline in the second and third assessments though they were not statistically significant. It is necessary to state here that particularly the clinical setting was an important impact. This can be interpreted as handling the routine practices predominantly in clinical settings, the lack of suitable role models, insufficient number of nurses in the health system, deficiencies in the cooperation of education and implementation, considering the nursing process and scientific problem solving process as challenging by nurses and time consuming in theory and practice, and insufficient utilization of the nursing process system in clinical nursing practices.

It was found at the end of the fall term in our study that the problem solving skills of experimental group students were higher than those of control group students. However, there was not a statistically significant difference between sub-scale scores and total scores of students' problem solving skills at the end of the spring term $(p>0,05)$. This result suggested that the students in the experimental group floundered in the face of a new training approach.

Problem solving skill is also affected by the accumulation of remedial actions that an individual uses to cope with problems that have been brought from the past up to the present time (Tok \& Sevinc, 2010). Therefore, students coming from a traditional education system cannot be expected to change their learning and thinking styles in just one single academic term. Indeed, when the effect of concept mapping technique use on students' academic achievement was evaluated, it was determined that the highest effect was at high school level and the lowest was at university level (Batdı, 2014). In this study, the academic mean score of the group studying with concept map was determined to yield a relative increase.

The problem solving skills of the male students in the experimental group were higher than those of female students at the beginning and end of the fall term. However, male students in Turkey have been admitted to nursing education since 2007 and their population is quite small (Saritas, Karadag, \& Ayar, 2009). While there was not a significant difference between the scores of male and female students' problem solving skills in studies conducted with university students from various fields in our 
Karadag, M., Demir, S. G., Bulut, H., Erden, S., Demir, N., Erdogan, Z. \& Ay, A. (2017), The effect of concept map based education on the problem solving skills of students. New Trends and Issues Proceedings on Humanities and Social Sciences. [Online]. 01, pp 506-513. Available from: $\underline{w w w . p r o s o c . e u}$

country (Dundar, 2009; Olgun, Onturk, Karabacak, Aslan, \& Serbest, 2010; GungOr, 2012; Yenice, 2012), it was determined that the problem solving skills of female students were developed in some of the studies (Keskin \& Yıldırım, 2008) and those of male students in others (Kolayıs, Turan, \& Ulusoy, 2012; Uslu \& Girgin, 2010).

\section{Conclusion}

It was determined in this study that the problem solving skills of nursing students were similar to the problem solving skills of other university students in our country, and that their problem solving levels were above intermediate level. In addition, according to the findings obtained from the study, there was not a difference between the traditional method and the concept mapping method in terms of developing students' problem solving skills. It can be recommended that nursing educators should employ teaching and learning methods more that develop students' creativity (Karadag et al 2014, Karadag et al 2009), problem solving skills, critical thinking, sophisticated thinking and reasoning, and that such factors as personality traits and self-esteem which affect problem solving skills should be investigated.

\section{References}

All, A., \& Havens, R. (1997). Cognitive/concept mapping: A teaching strategy in nursing. Journal of Advanced Nursing, 25(6), 1210-1219.

Altun, I. (2003). The perceived problem solving ability and values of student nurses and midwives. Nurse Education Today, 23,575-584.

Atay, S., \&, Karabacak, U. (2010). Student views on concept map and preparing care plan with concept mapping. Maltepe University Journal of Nursing Science and Art, 3(3), 45-53.

Austin Community College District. (n.d.). Critical thinking strategies: Concept mapping. Retrieved October 25, 2013 from http://www.austincc.edu/adnfac/collaborative/onsite_conceptmap.htm.

Batdı, V. (2014). The effect of concept mapping technique and traditional learning methods on student achievement, retention of information and attitudes: A meta-analysis study. Dumlupınar University Journal of Social Sciences, 42,93-102.

Chen, S.L., Liang, T.L., Lee, M.L., \& Liao, I.C. (2011). The effects of concept maps on students' critical thinking and approach to learning and studying. Journal of Nursing Education, 50 (8), 466-469.

Dundar, S. (2009). Investigating the relationship between the personal traits and problem solving skills of university students. Dokuz Eylul University Faculty of Economics and Administrative Sciences Journal, 24, 139-150.

Durmaz, S., Kacar, Z., Can, S., Koca, R., Yesilova, D., \& Tortumluoglu G. (2007). Canakkale Saglık Yuksekokulu Ogrencilerinin problem cozme becerileri (PCB) ve etkileyen bazı faktorler. Ataturk University Journal of Nursing School, 10(4), 63-71.

GungOr, M. (2012). Investigating the problem solving skills of university students in terms of family types and family attitudes. E-Journal Of New World Sciences Academy, 7( 4), 41-51.

Karadag, M, Saritas, S. Erginer, E.(2009).Using the 'six thinking hats' model of learning in a surgical nursing class: Sharing the experience and student opinions. Australian Journal of Advanced Nursing, 26,3, :59-69.

Karadag, M., Pekin, O., \& Etikan, I.(2014).Determining nursing student knowledge, behavior and beliefs for breast bancer and breast self-examination receiving courses with two different approaches. Asian Pacific Journal of Cancer Prevention, 15(9),3885-3890.

Kelleci, M., Golbası Z., Dogan, S., \& Tugut, N. (2011). Problem solving abilities of the nursing students studying in integrated education Program: A follow up study. Florance Nightingale Journal of Nursing, 19(1), 23-28.

Keskin, G., \& Yıldırım, G.O. (2008). The evaluation of university students in terms of problem solving, autonomy, multiple intelligences based on constructive approach norms. Inonu University Journal of the Faculty of Education, 9(16), 67-88. 
Karadag, M., Demir, S. G., Bulut, H., Erden, S., Demir, N., Erdogan, Z. \& Ay, A. (2017), The effect of concept map based education on the problem solving skills of students. New Trends and Issues Proceedings on Humanities and Social Sciences. [Online]. 01, pp 506-513. Available from: www.prosoc.eu

Kolayıs, H., Turan, H. \& Ulusoy, Y.O. (2012). Comparison of problem-solving disposition of students in physical education teacher and psychological counseling and guidance. Procedia-Social and Behavioral Sciences, 46,1939-1942.

Lee, W., Chiang, C.H., Liao, I.C., Lee, M.L., Chen, S.L., \& Liang, T. (2013). The longitudinal effect of concept map teaching on critical thinking of nursing students. Nurse Education Today, 33(10),1219-23.

Mahmoud, H.G. (2012). Critical thinking dispositions and learning styles of baccalaureate nursing students and its relation to their achievement. International Journal of Learning \& Development, 2 (1), 398-415.

Olgun, N., Onturk, Z.K., Karabacak, U., Aslan, F.E., \& Serbest, S. (2010). The problem solving skills of nursing students: Follow up results of one year. Acıbadem University Journal of Health Sciences, 1, 188-194.

Pickens, C.L. (2007). Concept mapping: methods to improve critical thinking (Unpublished Doctoral Dissertation). Wayne State University, Michigan.

Saritas, S., Karadag , M., \& Ayar, D. (2009). School for health sciences university students' opinions about male nurses, Journal of Professional Nursing, 25(5), 279-284.

Taylan, S. (1990). Validity and reliability study of Heppner's Problem Solving Inventory (Unpublished Master Dissertation). Ankara University Social Sciences Institute, Ankara.

Tok, E. \& Sevinc, M. (2010). The effect of thinking skills education on critical thinking and problem solving skills. Pamukkale University Journal of Education, 27, 67-82.

Uslu, M., \& Girgin, C. (2010). The effects of residential conditions on the problem solving skills of university students. Procedia - Social and Behavioral Sciences, 2, 3031-3035.

Yenice, N. (2012). Investigating self-efficacy levels and problem solving skills of prospective teachers, Electronic Journal of Social Sciences, 2, 36-58.

Yurttas, A., \& Yetkin, A. (2003). Comparison of problem solving skills and empathetic skills of health sciences students. Ataturk University, Journal of Nursing School, 6 (1), 1-13. 